\title{
AUGUST 2011
}

VOLUME 5 NUMBER 8

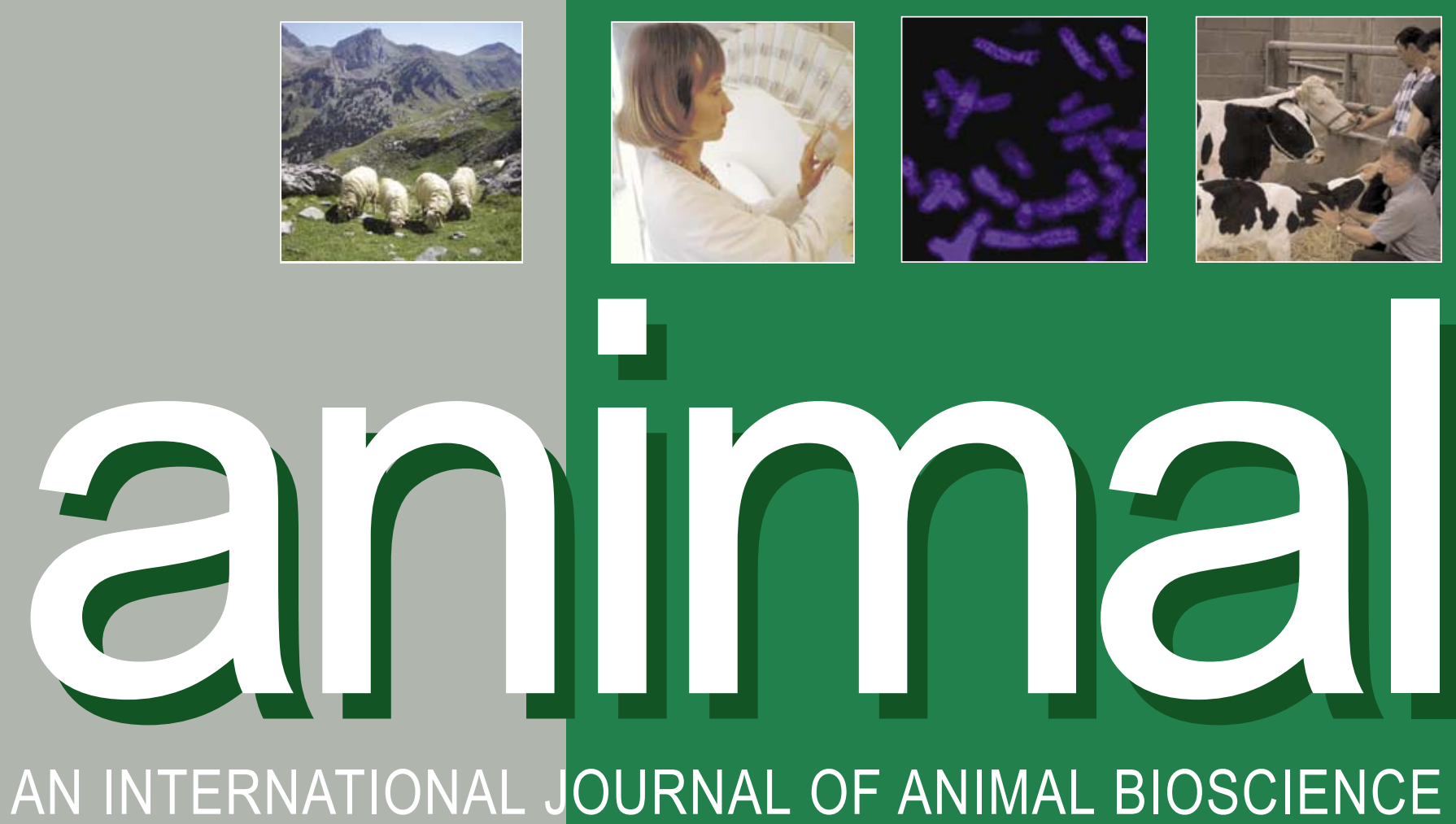




\section{ANIMAL}

\section{Editor-in-Chief}

M. Doreau, France

\section{Strategic Development Editor}

J. OLDHAM, UK

\section{Reviews}

K. SEJRSEN, Denmark

\section{Editorial Office}

Email: questions@animal-journal.eu

N. Miraux (Editorial Assistant),

B. Hilton, F. Ferguson and F. Normand

Section (SE) and Deputy Section

Editors (DSE)

J. WeLLeR (SE - Breeding and Genetics, Israel)

S. Rodriguez-ZAS (DSE - Breeding and Genetics, USA)

V. FIEVEZ (SE - Nutrition Ruminants, Belgium)

P. Moughan (SE - Nutrition

Nonruminants, New Zealand)

D. ToRRALLARDONA (DSE - Nutrition

Nonruminants, Spain)

I. Ortigues-Marty (DSE - Nutrition

Ruminants, France)

R. HILL (SE - Physiology and Functional Biology of Systems, USA)

M. VestergaArd (DSE - Physiology and Functional Biology of Systems,

Denmark)

S. EdwARDS (SE - Behaviour, Health and Welfare, UK)

M. Cockram (DSE - Behaviour, Health and Welfare, Canada)

A. Bernues (SE - Farming Systems and Environment, Spain)

M. GaULY (DSE - Farming Systems and Environment, Germany)

A. BALDI (SE - Product Quality, Human Health and Well-Being, Italy)

K. SHINGFIELD (DSE - Product Quality, Human Health and Well-Being, Finland)

\section{Editors}

\section{Breeding and Genetics:}

M. Calus (The Netherlands),Y. DA (USA), H. KhatiB (USA), C. KüHn (Germany),

A. Malau-Aduli (Australia), R. Mrode (UK), J. SZYDA (Poland)

Nutrition: J. Brameld (UK), R. Dewhurst

(Ireland), L. Doepel (Canada), W. GerRiTs

(The Netherlands), R. Gervals (Canada),

E.J. KIM (UK), S. MACKENZIE (UK),

W. Martin-Rosset (France), J. Newbold

(Belgium), D. PACHECO (New Zealand),

M. J. RaNiLLA (Spain), R. RavindRAN

(New Zealand), N. Scollan (UK),

K.H. SÜDEKUM (Germany),

N. Trottier (USA), J. Van Milgen (France),

A. VAN VuUREN (The Netherlands),

B. Williams (Australia)

Physiology and Functional Biology of

Systems: G. DAHL (USA),

G. Gonzalez Mariscal (Mexico),

G. Hausman (USA), K. Holtenius

(Sweden), D. KENNY (Ireland),

P. Lacasse (Canada), D. Miller (USA),

P. MOZDZIAK (USA), R. RAMACHANDRAN

(USA), G. VATZIAS (Greece),

P. WYNn (Australia)
Behaviour, Welfare and Health:

A. BoIssy (France), E. von BoreLL (Germany), U. Emanuelson (Sweden),

C. Fourichon (France), H. JuUL-MAdSEN

(Denmark), X. MANTECA (Spain),

B. Nielsen (Denmark),

E. WatTRANG (Sweden)

Farming Systems and Environment:

A. Adesogan (USA), H. CLARK

(New Zealand), A. Duncan (Ethiopia),

N. Miraglia (Italy), A. Moloney (Ireland),

B. Nicks (Belgium), H. POULSEN

(Denmark), J. T. SORENSEN (Denmark),

V. VASTA (Italy)

Product Quality, Human Health and

Well-Being: M. CAMPO (Spain)

I. GIVENS (UK)

Aims and Scope of the journal

Animal is a completely new entity that seeks to attract the best research in animal biology and animal systems from across the spectrum of the agricultural, biomedical, and environmental sciences; it is the central element in an exciting collaboration between the British Society of Animal Science (BSAS), the Institut National de la Recherche Agronomique (INRA) and the European Association of Animal Production (EAAP) and represents a merging of the three scientific journals: Animal Science; Animal Research; Reproduction, Nutrition, Development. Animal will publish original cutting-edge research, 'hot' topics and horizon-scanning reviews on animalrelated aspects of the life sciences at the molecular, cellular, organ, whole animal and production system levels.

The main subject areas include: breeding and genetics; nutrition; physiology and functional biology of systems; behaviour, health and welfare; farming systems, environmental impact and climate change; product quality, human health and wellbeing. Animal models and papers dealing with the integration of research between these topics and their impact on the environment and people will be particularly welcome. The detailed scope of the journal can be found at www.animal-journal. eu/scope.htm

\section{Submission of Manuscripts}

All manuscripts must be submitted online via the website: http://www.editorial manager.com/animal/

Please consult the full instructions for authors at: www.animal-journal.eu/ instructions_to_authors.htm

\section{Subscriptions}

Animal (ISSN 1751-7311) is published monthly. The subscription price for institutions of Volume 5 (2011) which includes electronic access and delivery by air is £685, €915 (US \$1340 in the USA, Canada and Mexico); the electronic only price for institutions is $£ 578, € 790$ (US $\$ 1160$ in the USA, Canada and Mexico). Single parts are $£ 62$, $€ 75$ (US $\$ 122$ in the USA, Canada and Mexico), plus postage.

Orders, which must be accompanied by payment, may be sent to a bookseller, subscription agent or direct to the publisher: Cambridge University Press, The Edinburgh Building, Shaftesbury Road,
Cambridge CB2 8RU, UK; or in the USA, Canada and Mexico: Cambridge University Press, Journals Fulfillment Department, 100 Brook Hill Drive, West Nuack, New York, 10994-2133. EU subscribers (outside the UK) who are not registered for VAT should add VAT at their country's rate. VAT registered subscribers should provide their VAT registration number. Japanese prices for institutions are available from Kinokuniya Company Ltd, P. O. Box 55 Chitose, Tokyo 156, Japan.

Copies of the journal for subscribers in the USA, Canada and Mexico are sent by air to New York to arrive with minimum delay. Periodicals postage paid at New York, NY, and at additional mailing offices. Postmaster: send address changes in the USA Canada and Mexico to: Animal, Cambridge University Press, 100 Brook Hill Drive, West Nyack, New York 10994-2133. Claims for missing issues should be made immediately on receipt of the subsequent issue.

\section{Advertising}

Advertising queries for all parts of the world except the USA, Canada and Mexico to ad_sales@cambridge.org

Address enquiries in the USA, Mexico and Canada only to:

journals_advertising@cup.org

\section{Copying}

This journal is registered with the Copyright Clearance Centre, 222 Rosewood Drive, Danvers, MA 01923. USA.

Organizations in the USA who are also registered with C. C. C. may therefore copy material (beyond the limits permitted by sections 107 and 108 of U.S. Copyright law) subject to promotional or commercial purposes. Code 0266-4674/2011 \$16.00.

ISI Tear Sheet Service, 3501 Market Street, Philadelphia, PA 19104, USA is authorized to supply single copies of separate articles for private use only. Organizations authorized by the Copyright Licensing Agency may also copy material subject to the usual conditions. For all other use, permission should be sought from Cambridge or the American Branch of Cambridge University Press.

Internet Access

This journal is included in the Cambridge Journals Online Service which can be found at www.journals.cambridge.org

\section{Front cover images}

Mountain scene photograph courtesy of Julian Casasús. Other images (C) INRA Picture Library.

This journal issue has been printed on FSC-certified paper and cover board. FSC is an independent, non-governmental, not-for-profit organization established to promote the responsible management of the World's forests. Please see www.fsc.org for information.

Printed in the UK by Bell \& Bain Ltd. Glasgow.

C Animal Consortium 2011 


\section{animal}

\section{AN INTERNATIONAL JOURNAL OF ANIMAL BIOSCIENCE}
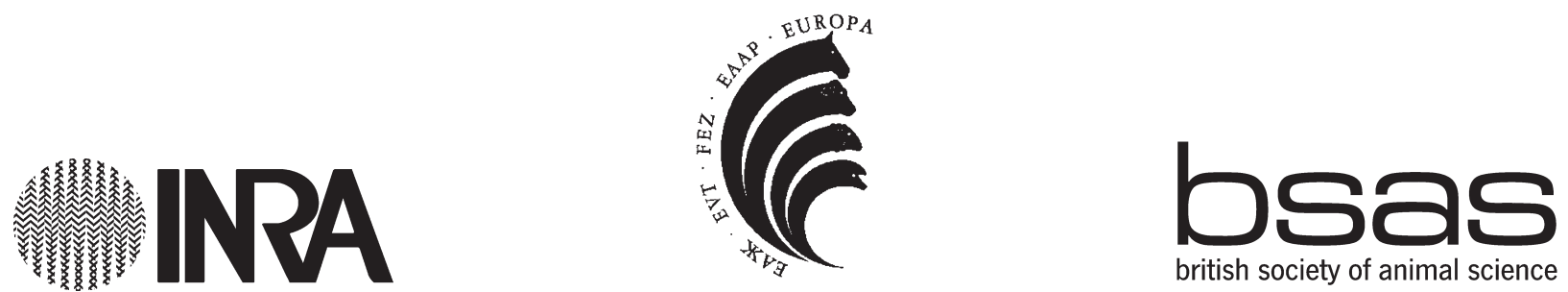


\section{CAMBRIDGE JOURNALS}

\section{Parasitology}

Editor-in-Chief

R. S. Phillips, University of Glasgow, UK

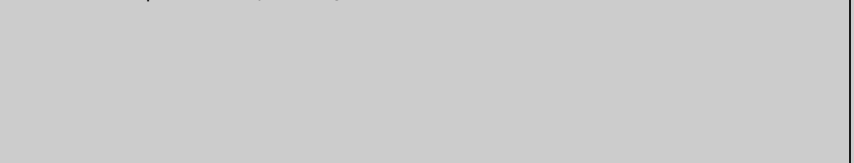

Parasitology is an important specialist journal covering the latest advances in the subject. It publishes original research and review papers on all aspects of parasitology and host-parasite relationships, including the latest discoveries in parasite biochemistry, molecular biology and genetics, ecology and epidemiology in the context of the biological, medical and veterinary sciences. Included in the subscription price are two special issues which contain reviews of current hot topics in parasitology, one of which is the proceedings of the annual Symposium of the British Society for Parasitology, while the second, covering areas of significant topical interest, is commissioned by the editors and the editorial board.

Price information

is available at: http://journals.cambridge.org/par

\section{Free email alerts}

Keep up-to-date with new material - sign up at http://journals.cambridge.org/par-alerts

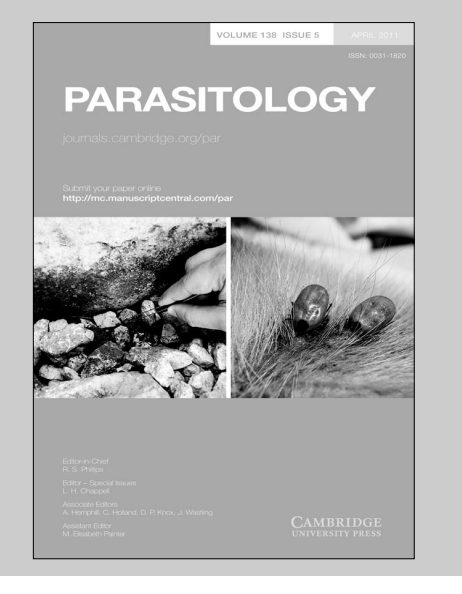

Parasitology

is available online at:

http://journals.cambridge.org/par

To subscribe contact

Customer Services

in Cambridge:

Phone +44 (0)1223 326070

Fax +44 (0)1223 325150

Email journals@cambridge.org

in New York:

Phone +1 (845) 3537500

$\mathrm{Fax}+1(845) 3534141$

Email

subscriptions_newyork@cambridge.org

For free online content visit: http://journals.cambridge.org/par 